\title{
Peningkatan Pertumbuhan Bibit Pisang Barangan dengan Aplikasi Fungi Mikoriza Arbuskular
}

\section{Increased Growth of Barangan Banana Seeds With Application of Arbuscular Mycorrhizal Fungi}

\author{
Khafiz, Suswati \& Asmah Indrawati \\ Fakultas Pertanian, Universitas Medan Area, Indonesia \\ *Corresponding author: E-mail: khafizumafp@gmail.com
}

\begin{abstract}
Abstrak
Tanaman pisang Barangan adalah komoditi penting yang sangat berperanan mendukung diversifikasi sumber pangan, ekonomi dan aktifitas budaya di Sumatera Utara dalam pengusahaannya penyakit Darah Bakteri yang disebabkan oleh Blood Disease Bacterium (BDB) Phylotipe IV dan Fusarium oxysporum f.sp.cubense (Foc) menjadi penyebab utama turunnya produksi pisang Barangan ini dan menyebabkan terkontaminasinya lahan tanam oleh propagul patogen.Untuk itu telah dilakukan penelitian tentang peningkatan pertumbuhan bibit pisang Barangan dengan Fungi Mikoriza Arbuskular. Tujuan penelitian ini adalah untuk menggali informasi tentang kemampuan FMA dalam meningkatkan pertumbuhan bibit pisang Barangan yang diperbanyak secara in-vitro. Rancangan yang digunakan adalah Rancangan Acak Lengkap (RAL) dengan 4 perlakuan dan 5 ulangan yaitu 1= Kontrol ( tanpa FMA ), 2 = Glomus tipe-1, 3= Acauluspora tipe-4, 4= Multispora. Parameter pengamatan: Persentese kolonisasi akar, Efektifitas simbiosis, Kepadatan Spora FMA, tinggi tanaman, jumlah daun.Hasil Penelitian menunjukkan bahwa semua dosis FMA yang digunakan sangat baik untuk membantu pertumbuhan dan tinggi tanaman pisang, Pengaplikasian FMA Glomus tipe-1, Acauluspora tipe-4, Multispora sangat berpengaruh nyata untuk parameter tinggi tanaman, jumlah daun dan berat basah tanaman pisang dan berpengaruh nyata untuk parameter berat shoot tanaman dan tidak berpengaruh nyata untuk berat basah root.
\end{abstract}

Kata Kunci: Peningkatan Pertumbuhan, Bibit Pisang Barangan, Fungi Mikoriza Arbuskular

\begin{abstract}
Barangan banana is an important commodity that plays an important role in supporting the diversification of food, economic and cultural activities in North Sumatera in the exploitation of Bacteria Blood Disease caused by Blood Disease Bacterium (BDB) Phylotipe IV and Fusarium oxysporum f.sp.cubense (Foc) the main decline of Barangan banana production and causing contamination of planting land by propagule pathogen.Untuk it has done research on increased growth of Barangan banana seedlings with Arbuscular Fungi Mikoriza. The purpose of this study was to explore information about the ability of FMA in increasing the growth of banana seedlings are propagated in-vitro. The design used was Completely Randomized Design (RAL) with 4 treatments and 5 replications ie $1=$ Control (without FMA), 2 = Glomerus type-1, 3 = Acauluspora type-4, 4 = Multispora. Observation parameters: Percentage of root colonization, symbiotic effectivity, Spora FMA density, plant height, number of leaves. The results of the study showed that all doses of FMA used were very good to assist growth and height of banana plants, FMA Glomus type-1 application, Acauluspora type-4, Multispora is highly significant for plant height parameters, leaf number and wet weight of banana plants and has significant effect on shoot weight parameter of plant and has no significant effect to wet root weight.
\end{abstract}

Keywords: Growth Increase, Barangan Banana Seeds, Arbuscular Fungi Mycorrhiza

How to Cite: Khafiz, Suswati \& Asmah, I. (2018). Peningkatan Pertumbuhan Bibit Pisang Barangan dengan Aplikasi Fungi Mikoriza Arbuskular, Agrotekma, 2 (2): 81- 90. 
Khafiz, Suswati \& Asmah Idrawati, Peningkatan Pertumbuhan Bibit Pisang Barangan dengan Aplikasi

\section{PENDAHULUAN}

Tanaman pisang Barangan adalah komoditi penting yang sangat berperananmendukung diversifikasi sumber pangan, ekonomi dan aktifitas budaya di Sumatera Utara.Komoditi ini mendukung roda perekonomian masyarakat di sentra penghasil pisang di Sumatera Utara. Pisang Barangan merupakan pisang olah unggul yang memiliki warna, rasa dan tekstur yang sangat disukai oleh penggemar pisang meja di Sumatera Utara. Namun semenjak tahun 1990an, pertanaman pisang di Sumatera Utara rusak berat akibat serangan penyakit layu pisang. Salah satu penyebab turunnya produksi pisang Barangan di Indonesia terutama Sumatera Utara adalah penyakit Darah Bakteri yang disebabkan oleh Ralstonia solanacearum spesies Phylotipe IV.

Untuk mempercepat rehabilitasi lahan yang tercemar propagul patogen tersebut serta mendukung program nasional revitalisasi pisang dalam rangka penyediaan bibit sehat/bermutu dan ketahanan pangan, revitalisasi perekonomian pisang serta isu pemeliharaan lingkungan menekan penggunaan pupuk dan pestisida kimia perlu dilakukan upaya budidaya pisang sesuai dengan Good Agricultural Practices (GAP) dan Standard Operasional Prosedure
(SOP) dengan menerapkan sistem pengendalian terpadu (Integrated Pest Management) yang ramah lingkungan. Hasil berbagai penelitian diketahui bahwa Fungi Mikoriza Arbuskular (FMA) dapat menekan propagul infektif patogen. Pengujian FMA-PU10 yang diperoleh dari rizosfer tanaman pisang kultivar Barangan sehat di lahan endemik penyakit darah bakteri Pasar Usang Sumatera Barat dapat mengurangi jumlah propagul infektif Darah Bakteri dalam pengujian rumah kaca (Suswati et al, 2007) dan lapangan (Suswati et al, 2008). Disamping itu FMA tersebut dapat meningkatkan ketahanan tanaman terhadap patogen, memperbaiki kualitas pertumbuhan dan produksi di lahan endemik Darah Bakteri.

Dengan situasi perpisangan yang rusak berat akibat serangan penyakit darah bakteri dan Layu Fusarium di Sumatera Utara khususnya Kabupaten Deli Serdang maka sangat diperlukan sebuah inovasi yang adaptif yang didukung oleh tekhnologi dalam penyediaan bibit sehat.Untuk itu perlu dilakukan inovasi teknologi penggunaan bibit hasilkultur jaringan dan induksi FMA. Tujuan dari penelitian ini adalah untuk menggali informasi tentang kemampuan FMA dalam meningkatkan pertumbuhan bibit pisang Barangan yang diperbanyak secara invitro. 


\section{METODE PENELITIAN}

Bahan-bahan yang digunakan dalam penelitian ini adalah plantlet pisang Barangan, tanah ultisol halus dan pupuk kandang diayak halus, inokulan FMA (koleksiSuswati (2007) Laboratorium Agroteknologi Fakultas Pertanian, Universiitas Medan Area). Pupuk TSP, fuchsin acid, $\mathrm{KOH} 10 \%, \mathrm{H}_{2} \mathrm{O}_{2}, \mathrm{HCl} 2 \%$, larutan laktofenol (asam laktat : gliserol : air destilasi), larutan sukrosa, dan aquadest, larutan Melzer's, PVLG. Sedangkan alat-alat yang digunakan dalam penelitian ini terdiri atas polybag ukuran $15 \mathrm{X} 20 \mathrm{~cm}, 30$ x $40 \mathrm{~cm}$, mikroskop cahaya, mikroskop binokuler, petridish, gelas objek, cover glass, plastik bening, pinset, timbangan analitik, oven, hand sprayer, gelas piala, tabung reaksi, botol sampel, ayakan pasir, jangka sorong, skop kecil, waterbath, gunting dan alat tulis.

Rancangan yang digunakan adalah Rancangan Acak Lengkap (RAL) dengan 4 perlakuan dan 5 ulangan. Perlakuan adalah aplikasi jenis isolat Fungi Mikoriza Arbuskular (FMA) sebagai berikut:

A0 $=$ Kontrol (tanpa inokulan)

A1 = 10 g inokulan (Glomus tipe-1)

A2 = 10 g inokulan (Acaulospora tipe-4)

$\mathrm{A} 3=10 \mathrm{~g}$ inokulan (Multispora)

Media tanam merupakan tanah Ultisol dari kebun percobaan Fakultas Pertanian, Universitas Medan Area. Tanah diambil secara komposit pada kedalaman 0-20 cm (lapisan olah), dikeringanginkan dan dihaluskan serta diayak dengan ayakan berdiameter $2 \mathrm{~mm}$, dicampur rata selanjutnya disterilisasi secara bertahap pada suhu $100^{\circ} \mathrm{C}$ sampai 3 x (Tyndalisasi). Setelah dingin, $8 \mathrm{~kg}$ tanah dimasukkan kedalam polybag volume $10 \mathrm{~kg}$, disiram hingga kapasitas lapang dan dibiarkan 24 jam. Bibit umur 14 hari setelah aklimatisasi dipindah ke dalam polybag.

Planlet pisang yang digunakan adalah kultivar Barangan yang berasal dari Perusahaan swasta kultur jaringan Tanjung Morawa, Medan. Plantlet tersebut merupakan hasil perbanyakan in-vitro. Plantlet pisang dikeluarkan dari dalam botol, dicuci dengan air yang mengalir hingga media agar tidak melekat, selanjutnya dikeringanginkan. Untuk merangsang pembentukan akar maka akar planlet digunting sampai $2 \mathrm{~cm}$.

Sumber inokulan FMA yang digunakan adalah dalam bentuk campuran media tanam pasir yang mengandung spora, hifa eksternal dan potongan akar tanaman jagung yang terkolonisasi FMA. Aplikasi FMA bersamaan waktunya dengan aklimatisasi plantlet. Bagian tengah media aklimatisasi (campuran pupuk kandang : arang sekam (1:3) dan kompos kulit kopi) dari masing-masing polybag ukuran 12x15 $\mathrm{cm}$ dibuat lubang sedalam lebih kurang 5 
cm ditaburkan $10 \mathrm{~g}$ inokulan FMA yang mengandung lebih kurang 100 spora, ditutup dengan selapis tanah $(2 \mathrm{~cm})$ kemudian plantlet ditanam.

Untuk menjaga agar tetap lembab maka bibit disungkup dengan plastik transparan dengan pencahayaan $60 \%$. Bibit dipelihara sampai umur 14 hari dan selanjutnya dipindahkan ke polybag ukuran 30x40 cm yang berisi $8 \mathrm{~kg}$ campuran tanah dan pupuk kandang (3:1) yang telah disterilisasi. Pada saat yang bersamaaan dilakukan pemupukan dengan Urea, TSP dan KCl. Pemupukan dilakukan sekali sebulan dengan $25 \%$ dosis rekomendasi. Untuk 1 ha pisang memerlukan $207 \mathrm{~kg}$ urea, $138 \mathrm{~kg}$ super fosfat dan $608 \mathrm{~kg} \mathrm{KCl}$ (Subakti dan Supriyanto, 1996). Bibit disiram setiap hari sampai kapasitas lapang. Penyiangan gulma dan pengendalian hama dilakukan secara manual

Persentase bibit tumbuh sejak aklimatisasi plantlet sampai bibit berumur 30 hari dengan selang waktu 7 hari. Dihitung dengan rumus : $\mathrm{TT}=\mathrm{a} / \mathrm{b} \times 100 \%$, $\mathrm{TT}=$ persentase tanaman tumbuh, $\mathrm{a}=$ jumlah tanaman yang hidup, $\mathrm{b}=$ total tanaman.

Tinggi bibit diukur mulai dari leher akar sampai pada bagian tumbuhnya daun paling muda. Pengamatan dimulai saat bibit berumur 1 minggu setelah tanam sampai 90 hsa dengan interval sekali seminggu. Jumlah daun dihitung untuk daun yang telah membuka sempurna. Pengamatan dimulai saat bibit berumur 1 minggu setelah tanam sampai 90 hsa dengan interval sekali seminggu.

Persentase kolonisasi FMA dihitung dengan metode slide (Giovannetti dan Mosse, 1980). Bidang pandang yang menunjukkan tanda-tanda kolonisasi (terdapat vesikel dan atau arbuskular atau hifa) diberi tanda (+) sedangkan yang tidak ditemukan tanda-tanda kolonisasi diberi tanda $(-)$, dapat dihitung berdasarkan rumus sebagai berikut:

$\%$ kolonisasi akar $=$

$\Sigma$ Bidang pandang tanda $+\quad \mathrm{x} 100 \%$

$\Sigma$ Bidang pandang keseluruhan(Rumus1)

Tabel 3.1.Kriteria penilaian persentase kolonisasi akar (Giovannetti dan Mosse,(1980) cit Setiadi et al., 1992.

\begin{tabular}{l|l}
\hline Kelas & Kategori kolonisasi \\
\hline 1 & $0-5 \%$ (sangat rendah) \\
2 & $6-26 \%$ (rendah) \\
3 & $26-50 \%$ ( sedang) \\
4 & $51-75 \%$ (tinggi) \\
5 & $76-100 \%$ (sangat tinggi) \\
\hline
\end{tabular}

Sumber: The Institute of Mycorhizal Research and Development, USDA ForestServiceFeorgia (cit Setiadi et al., 1992)

Efektifitas simbiosis (RMD) antara FMA dengan tanaman pisang Barangan dapat dihitung berdasarkan rumus Munyanziza et al, 1997; Brundrett, 1999) : 
$\mathrm{RMD}=(\mathrm{BKM}-\mathrm{BKTM})(\mathrm{BKM})^{-1} \times 100 \%$ (Rumus 2)

$\mathrm{BKM}=$ bobot kering tanaman yang diinokulasi FMA

BKTM = bobot kering tanaman yang tidak diinokulasi FMA

Kepadatan spora per 10 g media tanam bibit pisang kultivar Barangan dihitung pada 30, 60 dan 90 hari setelah introduksi FMA.

Bobot Basah Panen, Bobot Shoot / Root Tanaman Pisang

Berat basah bibit pisang dan akarnya ditimbang setelah dipanen umur 3 bulan. Berat kering bibit ditimbang setelah dikeringkan dengan oven pada suhu $65{ }^{\circ} \mathrm{C}$ selama 48 jam (setelah beratnya konstan).

\section{HASIL DAN PEMBAHASAN}

Dari penelitian yang telah dilakukan tentang pertumbuhan tanaman Pisang Barangan yang diinokulasi Fungi Mikoriza Arbuskular (FMA) selama 10 minggu diperoleh hasil sebagai berikut:

Data pengamatan persentase tumbuh tanaman pisang Barangan dapat dilihat pada Tabel 4.1. Dimana tanaman pisang Barangan menunjukkan persentase tumbuh yang baik untuk semua perlakuan dengan menggunakan aplikasi FMA. Persentase tumbuh tanaman pisang Barangan yang terdapat pada semua perlakuan $\quad$ yaitu $\quad 100 \%$.

Tabel 4.1. Persentase, efektifitas dan persentase tumbuh tanaman pisang setelah Aplikasi FMA

\begin{tabular}{l|l|l|l|l}
\hline Kode & Perlakuan & $\begin{array}{l}\text { Jumlah tanaman } \\
\text { yang tumbuh }\end{array}$ & $\begin{array}{l}\text { Tanaman } \\
\text { hidup (\%) }\end{array}$ & $\begin{array}{l}\text { Efektivitas } \\
(\%)\end{array}$ \\
\hline A1 & Glomus tipe-1 & 5 & 100 & 100 \\
A2 & Acauluspora tipe-4 & 5 & 100 & 100 \\
A3 & Multispora & 5 & 100 & 100 \\
A0 & Kontrol & 5 & 100 & 100 \\
\hline
\end{tabular}

Tinggi tanaman digunakan sebagai Glomustipe-1 memperlihatkan salah satu indikator efektifitas kinerja kemampuan yang lebih tinggi, diikuti oleh isolat FMA. Semua isolat FMA dapat Acauluspora tipe-4 dan Multispora. Hasil meningkatkan tinggi tanaman bibit pisang uji statistik pengamatan tinggi tanaman Barangan (Tabel 4.2). Ketiga isolat FMA dan jumlah daun menunjukan pengaruh memiliki kemampuan tinggi dalam yang sangat nyata, pada parameter tinggi meningkatkan laju pertambahan tinggi tanaman perlakuan terbaik terdapat pada tanaman dan jumlah daun. Glomus tipe-1 pengaplikasian (A1) rata-rata tinggi paling baik meningkatkan tinggi tanaman tanaman mencapai $24,28 \mathrm{~cm}$, perlakuan pisang Barangan. Seiring dengan (A0) menunjukan rata-rata tinggi tanaman pertambahan umur tanaman isolat terendah yaitu mencapai 13,56 cm. 
Efektifitas pertumbuhan dengan perlakuan perlakuan (A2 dan A3) mencapai 14,89\%. (A1) mencapai $79.05 \%$ di susul dengan

Tabel 4.2. Rerata tinggi tanaman pisang Barangan umur 35, 56, dan 90 hsa

\begin{tabular}{|l|l|l|l|l|l|l|l|}
\hline \multirow{2}{*}{ Kode } & \multirow{2}{*}{ Perlakuan } & \multicolumn{6}{|l|}{ Rerata tinggi tanaman pada umur...........hari } \\
\cline { 3 - 8 } & & 35 & Eff $(\%)$ & 56 & Eff $(\%)$ & 90 & Eff (\%) \\
\hline A0 & Kontrol & $5.58 \mathrm{~d}$ & 0 & $9.54 \mathrm{~d}$ & 0 & $13.56 \mathrm{~d}$ & 0 \\
A1 & Glomus tipe-1 & $10 \mathrm{a}$ & 75.26 & $14.08 \mathrm{a}$ & 47.58 & $24.28 \mathrm{a}$ & 79.05 \\
A2 & Acauluspora tipe-4 & $7.7 \mathrm{bc}$ & 37.99 & $11.18 \mathrm{bc}$ & 17.19 & $15.84 \mathrm{bcd}$ & 14.89 \\
A3 & Multispora & $6.62 \mathrm{c}$ & 18.63 & $10.44 \mathrm{c}$ & 9.43 & $15.84 \mathrm{~cd}$ & 14.89 \\
\hline
\end{tabular}

Adanya simbiosis mutualistik antara FMA dengan perakaran tanaman dapat membantu pertumbuhan tanaman menjadi lebih baik. Hal ini menurut Allsopp dan Stock (1993), disebabkan FMA efektif dalam meningkatkan penyerapan unsur hara makro dan mikro, serta meningkatkan daya tahan tanaman terhadap serangan patogen (Wani, 1991). Ada tiga alasan mengapa FMA dapat meningkatkan penyerapan hara dalam tanah, yaitu karena FMA dapat: (1) mengurangi jarak bagi hara untuk memasuki akar tanaman, meningkatkan rata-rata penyerapan hara dan konsentrasi hara pada permukaan penyerapan dan (3) merubah secara kimia sifat-sifat hara sehingga memudahkan penyerapannya ke dalam akar tanaman.

Untuk parameter jumlah daun perlakuan terbaik ditunjukkan dengan pengaplikasian (A1) rata-rata jumlah daun mencapai 15,2 helai, sedangkan untuk perlakuan yang lain rata-rata jumlah daun mencapai 14 helai. Efektivitas pertamabahan jumlah daun dengan perlakuan (A1) mencapai 8,57\%.

Introduksi FMA mempengaruhi jumlah daun tanaman pisang Barangan pada 14 hsa. Kemampuan Glomus tipe-1 dalam meningkatkan jumlah daun lebih tinggi dibanding 2 isolat FMA lainnya. Dari hasil pengamatan terhadap rata-rata pertambahan jumlah daun dapat dilihat bahwa rata-rata pertambahan jumlah daun setiap perlakuan hampir sama, baik pada kontrol maupun yang diinokulasi dengan Acaulosporatipe-4 ataupun Multispora seperti yang disajikan pada Gambar 4.3. Hal ini dikarenakan karena kedua isolat FMA tersebut memiliki kemampuan simbiosis dengan bibit tanaman pisang Barangan. Menurut Setiadi (2007), tingkat ketergantungan tanaman terhadap FMA selain ditentukan oleh tanaman itu sendiri, juga ditentukan oleh jenis isolat FMA yang dipakai. Berikut tabel efektivitas pengaplikasian A0, A1, A2, A3 terhadap pertumbuhan jumlah daun tanaman pisang pada (Tabel 4.3). 
Tabel 4.3. Rerata Jumlah daun pisang Barangan umur 35, 56, dan 90 HSA

\begin{tabular}{llllllll}
\hline \multirow{2}{*}{ Kode } & Perlakuan & \multicolumn{6}{l}{ Rerata Jumlah daun pisang Barangan Umur..... hari } \\
\cline { 3 - 7 } & & 35 has & $\begin{array}{l}\text { Eff } \\
(\%)\end{array}$ & 56 hsa & Eff $(\%)$ & 90 has & Eff (\%) \\
\hline A0 & Kontrol & $6 \mathrm{~d}$ & 0 & $9 \mathrm{~d}$ & 0 & $14 \mathrm{~d}$ & 0 \\
A1 & Glomus tipe-1 & $7.2 \mathrm{a}$ & 20 & $10.2 \mathrm{a}$ & 13.3 & $15.2 \mathrm{a}$ & 8.57 \\
A2 & Acauluspora tipe-4 & $6 \mathrm{bcd}$ & 0 & $9 \mathrm{bcd}$ & 0 & $14 \mathrm{bcd}$ & 0 \\
A3 & Multispora & $6 \mathrm{~cd}$ & 0 & $9 \mathrm{~cd}$ & 0 & $14 \mathrm{~cd}$ & 0 \\
\hline
\end{tabular}

Perbedaan kemampuan isolat yang intensif akan membantu tanaman mikoriza sangat dipengaruhi oleh jenis menyerap hara dan air. Keberadaan FMA yang diberikan, umur tanaman pada struktur hifa eksternal yang saat introduksi FMA, jenis tanaman dan mengkolonisasi perakaran tanaman faktor lingkungan lain yang mendukung. pisang akan menambah luas permukaan Introduksi FMA pada saat aklimatisasi absorpsi dengan meningkatnya volume akan lebih cepat mengkolonisasi akar bidang penyerapan. dibandingkan dengan umur yang lebih Semua isolat FMA dapat lanjut. Selain itu perbedaan keefektivan tersebut disebabkan karena adanya perbedaan kemampuan dari masingmasing isolat dalam bersimbiosis dengan akar bibit pisang. Ada kemungkinan setiap isolat mempunyai preferensi yang berbeda terhadap eksudat yang dikeluarkan oleh bibit pisang tersebut. Menurut Singh et al. (2000); AzcónAguilar et al. (2002); Xavier dan Boyetchko.( 2004), keberhasilan introduksi FMA dalam peningkatan pertumbuhan tanaman akan ditentukan berbagai faktor diantaranya oleh jenis FMA, tingkat kolonisasi FMA, urutan mengkolonisasi dengan baik perakaran pisang Barangan dengan tingkat efektifitas kolonisasi $\leq 70 \%$ (Tabel 4.4). Persentase kolonisasi tertinggi ditemukan pada perakaran tanaman pisang Barangan yang dikolonisasi oleh Glomus tipe-1 (80.71\%) diikuti oleh Acauluspora tipe-4 dan Multispora masing-masing $\quad 70 \%$ Persentase kolonisasi, intensitas kolonisasi dan kepadatan spora mengalami peningkatan seiring dengan bertambahnya umur tanaman. Pada 60 hst persentase kolonisasi FMA telah mencapai 60\% $70 \%$ dengan kelas intensitas 2 (sedang).

introduksi, fase pertumbuhan tanaman dan jenis tanaman inang. Pertumbuhan yang baik didukung oleh kolonisasi yang baik pula. Perkembangan hifa eksternal 
Khafiz, Suswati \& Asmah Idrawati, Peningkatan Pertumbuhan Bibit Pisang Barangan dengan Aplikasi

Tabel 4.4. Persentase, intensitas dan efektifitas kolonisasi dan kepadatan spora FMA pada tanaman pisang Barangan umur 30 hsa dan 60 hsa

\begin{tabular}{llllllllll}
\hline \multirow{3}{*}{ Kode } & \multirow{3}{*}{ Perlakuan } & \multicolumn{4}{c}{ Intensitas kolonisasi FMA dan Kepadatan spora FMA } \\
& & \multicolumn{3}{c}{30 hsa } & \multicolumn{4}{c}{60 hsa } \\
\cline { 2 - 9 } & & PK & EK & IK & KS & PK & EK & IK & KS \\
\hline A1 & Glomus tipe-1 & 30 & 80.71 & 1 & 80 & 70 & 90.25 & 2 & 130 \\
A2 & Acauluspora tipe-4 & 20 & 70.00 & 1 & 70 & 70 & 90.25 & 2 & 120 \\
A3 & Multispora & 20 & 70.00 & 1 & 60 & 60 & 80.25 & 2 & 38 \\
kkkkA0 & Kontrol & 4 & 0.00 & 1 & 5 & 5 & 0.00 & 1 & 10 \\
\hline
\end{tabular}

Keterangan: $\mathrm{PK}=$ Persentase Kolonisasi, $\mathrm{IK}=$ Intensitas Kolonisasi, $\mathrm{KS}=\mathrm{KS}=$ Kepadatan spora per 10 gr; EK = Efektifitas Kolonisasi

Pada pengamatan mikroskopis pisang akan menambah luas permukaan ditemukan perakaran tanaman pisang absorpsi dengan meningkatnya volume Barangan telah terkolonisasi dengan baik bidang penyerapan akar. Semakin oleh isolat FMA. FMA berkembang di intensifnya perkembangan struktur jaringan korteks akar tanaman Barangan. kolonisasi FMA dapat dilihat dengan Struktur FMA seperti hifa berkembang semakin baiknya pertumbuhan tanaman. secara intensif selain itu juga ditemukan Efektivitas simbiosis tercermin dari Arbuskular, spora intradikal, vesikula dan peningkatan pertumbuhan dan hasil ekstra hifa matrikal (Gambar 4.1). tanaman. Secara umum efektivitas Keberadaan struktur hifa eksternal yang simbiosis FMA dengan tanaman pisang mengkolonisasi perakaran tanaman Barangan tergolong tinggi.
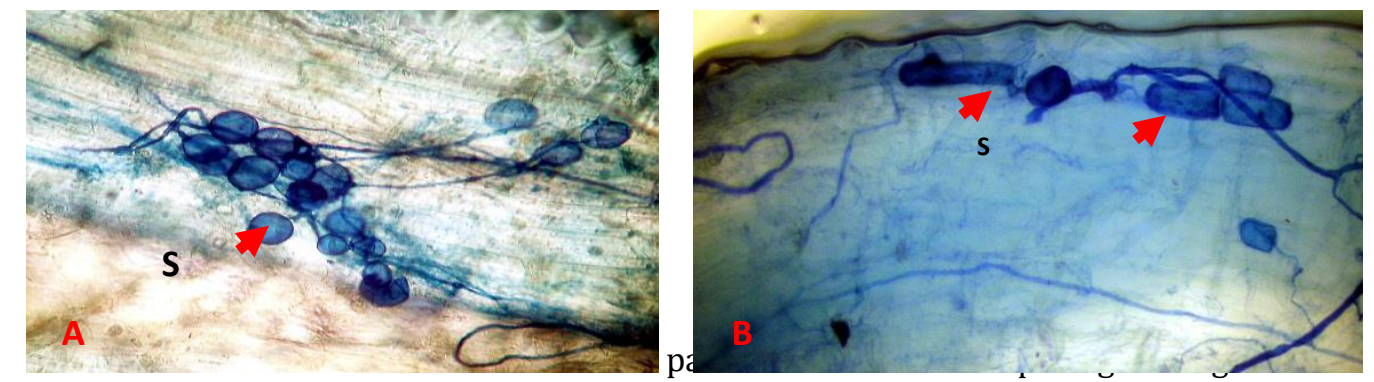

Keterangan : A . Stuktur Glomus tipe-1, B.Struktur kolonisasi Acaulospora tipe-4; a = arbuskular, he=hifa eksternal, $\mathrm{s}(\mathrm{S})=$ spora , perbesaran $100 \mathrm{x}$.

Hasil pengamatan untuk parameter bobot basah tanaman pisang pada umumnya semua isolat FMA yang diaplikasikan pada tanaman pisang mampu meningkatkan bobot basah tanaman berpengaruh sangat nyata (Tabel
4.5). Berat basah tanaman tertinggi diperoleh pada perlakuan dengan pengaplikasian multispora (A3) yaitu 178.6 g,dengan tingkat efektivitas penambahan bobot basah panen mencapai 137.18\%, diikuti dengan pengaplikasian 
Glomus tipe-1 (A2), yaitu 172.7g, dengan tingkat efektivitas penambahan bobot basah panen mencapai 129.34\%, dan pengaplikasian Acauluspora tipe-4 (A1) yaitu 171.1g, dengan tingkat efektivitas penambahan bobot basah panen mencapai $127.09 \%$, sementara kontrol hanya memperoleh rata-rata berat basah tanaman $75.3 \mathrm{~g}$.

Tabel 4.5. Rerata bobot basahpanen tanaman pisang umur 90 HSA.

\begin{tabular}{l|l|ll}
\hline \multirow{2}{*}{ Kode } & \multirow{2}{*}{ Perlakuan } & \multicolumn{2}{|c}{ Bobot basah panen } \\
\cline { 3 - 4 } & & $90 \mathrm{hsa}$ & Eff $(\%)$ \\
\hline A0 & Kontrol & $75.3 \mathrm{~d}$ & 0 \\
A1 & Glomus tipe-1 & $171.1 \mathrm{c}$ & 127.09 \\
A2 & Acauluspora tipe-4 & $172.7 \mathrm{bc}$ & 129.34 \\
A3 & Multispora & $178.6 \mathrm{abc}$ & 137.18 \\
\hline
\end{tabular}

Hasil pengamatan untuk parameter bobot basah shoot tanaman pisang pada umumnya semua isolat FMA yang diaplikasikan pada tanaman pisang mampu meningkatkan bobot basah batang tanaman, bobot basah batang tanaman menunjukan berpengaruh nyata. Berat basah shoot tanaman tertinggi diperoleh pada perlakuan dengan pengaplikasian Acauluspora tipe-4 (A2) yaitu 124.9 g, dengan tingkat efektivitas penambahan bobot basa shoot sebesar $176.32 \%$, diikuti dengan pengaplikasian Glomus tipe-1 (A1), yaitu 120.2g, dengan tingkat efektivitas penambahan bobot basahshoot sebesar 165.92\%, Multispora (A3) yaitu 90.3 g, dengan tingkat efektivitas penambahan bobot basahshoot sebesar 99.77\%, sementara kontrol hanya memperoleh rata-rata berat basah tanaman $45.2 \mathrm{~g}$. (Tabel 4.6)

Tabel 4.6. Berat basah shoot bibit pisang Barangan Umur 90 hsa

\begin{tabular}{l|l|ll}
\hline \multirow{2}{*}{ Kode } & \multirow{2}{*}{ Perlakuan } & \multicolumn{2}{|c}{ Bobot Basah Shoot } \\
\cline { 3 - 4 } & & $90 \mathrm{hsa}$ & Eff (\%) \\
\hline A0 & Kontrol & $45.2 \mathrm{~d}$ & 0 \\
A1 & Glomus tipe-1 & $120.2 \mathrm{~b}$ & 165.92 \\
A2 & Acauluspora tipe-4 & $124.9 \mathrm{ab}$ & 176.32 \\
A3 & Multispora & $90.3 \mathrm{c}$ & 99.77 \\
\hline
\end{tabular}

Hasil pengamatan untuk parameter bobot basah root tanaman pisang pada umumnya semua isolate FMA yang diaplikasikan pada tanaman pisang tidak mampu meningkatkan bobot basah root tanaman, bobot basah root tanaman menunjukan tidak pengaruh nyata. Berat basah root tanaman tertinggi diperoleh pada perlakuan dengan pengaplikasian Glomus tipe-1 (A1) yaitu 110.5, dengan tingkat efektivitas penambahan bobot basa root sebesar 267.1\%, diikuti dengan pengaplikasian Acauluspora tipe-4 (A2) yaitu $95.8 \mathrm{~g}$, dengan tingkat efektivitas penambahan bobot basah root sebesar 218.27, pengaplikasian Multispora (A3) yaitu $88.2 \mathrm{~g}$, dengan tingkat efektivitas penambahan bobot basah root sebesar193.02\%, sementara Kontrol hanya memperoleh rata-rata berat basah tanaman 45.2 g. ( Tabel 4.7 ) 
Khafiz, Suswati \& Asmah Idrawati, Peningkatan Pertumbuhan Bibit Pisang Barangan dengan Aplikasi

Tabel 4.7. Berat basah root bibit pisang Barangan Umur 90 hsa

\begin{tabular}{l|l|ll}
\hline \multirow{2}{*}{ Kode } & \multirow{2}{*}{ Perlakuan } & \multicolumn{2}{|c}{ Bobot Basah Root } \\
\cline { 3 - 4 } & & $90 \mathrm{hsa}$ & Eff $(\%)$ \\
\hline A0 & Kontrol & $30.1 \mathrm{~d}$ & 0 \\
A1 & Glomus tipe-1 & $110.5 \mathrm{abc}$ & 267.1 \\
A2 & Acauluspora tipe-4 & $95.8 \mathrm{bc}$ & 218.27 \\
A3 & Multispora & $88.2 \mathrm{c}$ & 193.02 \\
\hline
\end{tabular}

\section{SIMPULAN}

Secara umum Fungi Mikoriza

Arbuskular (Glomus tipe-1, Acauluspora tipe-4, Multispora) dapat meningkatkan pertumbuhan tanaman. Pengaplikasian

FMA Glomus tipe-1, Acauluspora tipe-4, Multispora berpengaruh sangat nyata untuk parameter tinggi tanaman, jumlah daun dan berat basah tanaman pisang dan berpengaruh nyata untuk parameter berat shoot tanaman dan berpengaruh tidak nyata untuk berat basah root.

\section{DAFTAR PUSTAKA}

Anonymous. (2004). http:// Invam. caf. wvu. edu/ fungi/taxonomy/classification.htm.on 10 Juli 2013.

Baharuddin, B. (1994). Pathological, Biochemical and Serological Characterization of the Blood Disease Bacterium Affecting Banana and Plantain (Musa sp) In Indonesia. Cuvillier Verlag Goettingen. 129p.

Buddenhagen, Z.W and Elasser, T.A. (19620. An Insect Spread wild Epiphytotic of Bluggoe Bananas. Nature 194: 146-165
Damarjati, D.S. (1999). Advancing Banana and Plantain $\mathrm{R}$ and $\mathrm{D}$ in Asia and the pacific: Research and Development of Banana in Indonesia. Proceeding of the 9th INIBAPAPSNET Regional Advisory Committee Meeting Held at South China Agricultural University, Guangzhou China, 2 - 5 November 1999

Giovannetti, M. and Mosse, B. (1980). An evaluation technique for measuring vesicular-arbuscular mychorrizal infection in roots. New Phytol. 84:489-500.

Harmet. (1999). Peranan G. fasciculatum dan pupuk fosfor dalam peningkatan ketahanan tanaman kedelai terhadap penyakit pustul bakteri (Xcg). Thesis program pascasarjana Universitas Andalas Padang. 73 hal.

Hermanto, C. (1998). Konfirmasi: Daerah endemik baru penyakit layu bakteri pisang di Sumatera Barat. Disampaikan pada seminar sehari PFI Komca Sumbar, Riau dan Jambi, Padang. 4 November 1998.

Husin. (1994). Mikrobiologi tanah. Universitas Andalas Padang. 151 halaman.

Imas, T., Hadioetomo, R.S, Gunawan, A.W dan Setiadi.Y (1989). Mikrobiologi Tanah. Ditjen Dikti Depdikbud. PAU-IPB.

Kobayashi, N and Branch, K. (1991). Biological control of soil borne disease with vesicular arbuscular mycorrhiza fungi and charcoal compost. In: Proceeding of the international seminar biological control of palnt disease and Virus vektor. Sept 17-21, Tsukuba. Japan. 153-160.

Setiadi, Y. (1989). Pemanfaatan mikroorganisme dalam kehutanan. PAU-IPB. Bogor. 6 halaman.

Sieverding, E. (1991). Vesicular- arbuscular mycorrhiza management in tropical agrosystems. GTZ GmbH. Germany. pp. 371.

Suprijadi. (2002). Perkembangan penelitian penyakit darah pada tanaman pisang dan strategi pengendaliannya. Gelar teknologi pengendalian lalat buah dan penyakit layu pisang. Direktorat perlindungan

Yusman. (2003). Uji kemampuan beberapa jenis FMA dalam menginduksi ketahanan tanaman tomat terhadap penyakit bercak bakteri (Xanthomonasaxonopodis pv. vesicatoria). 51 hal. 